\title{
Spontaneous Diabetes Mellitus in the Chinese Hamster: An Electron Microscopic Study of the Islets of Langerhans*
}

\author{
Sarait A. Luse, Felice Caramia, ** George Gerritsen and Willitam E. Dulin \\ Departments of Anatomy and Pathology, Washington University School of Medicine, St. Louis, Missouri, \\ and The Upjohn Company, Kalamazoo, Michigan
}

Summary. Islets of Langerhans of 15 Chinese hamsters ( 7 diabetic and 8 either related or unrelated controls of the same sox and age) have been examined by electron microscopy. Beta cells of control animals predominate and have abundant granules most of which are vesicles of varying sizes with a pale granular or homogeneous content. Only a few have a dense central core or irregular dense central bar. Alpha cells have uniformly round, dense, membrane-limited granules and are sparse except at the periphery of the islet. Farly in diabetes mellitus beta cells are abundant but either agranular or in various stages of glycogen storage. Late in the disease the islets are reduced to almost all alpha cells, the beta cells having gradually disappeared.

Diabète spontané du hamster chinois: étude au microscope électronique des îlots de Langerhans.

Résumé. Nous avons examiné au microscope électronique les îlots de Langerhans de 15 hamsters chinois dont 7 étaient diabétiques et 8 étaient non-diabétiques, provenant soit des mêmes nichées, soit sans lien de parenté, mais concordant quant au sexe et à l'âge. Chez les animaux de contrôle, les cellules $\beta$ prédominent et sont riches en granules, formés de vésicules de différentes tailles avec un contenu légèrement granulaire ou homogène. Dans de rares vésicules, on observe un noyau dense ou une barre centrale irrégulière et dense. Les granulations des cellules $\alpha$ sont uniformément rondes, très denses et limitées par des membranes; elles sont assez clairsemées à l'exception de la périphérie des îlots. Au début du diabète, les cellules $\beta$ sont abondantes mais, soit dégranulées, soit en voie d'infiltration glycogénique. Plus tardivement dans la maladie, les îlots ne contiennent presque que des cellules $\alpha$, les cellules $\beta$ ayant graduellement disparu.

Spontandiabetes beim chinesischen Hamster : elektronenoptische Untersuchung der Langerhans'schen Inseln.

Zusammenfassung. Die Langerhans'schen Inseln von 15 chinesischen Hamstern ( 7 diabetischen und 8 entweder verwandten oder nicht verwandten Kontrolltieren gleichen Geschlechts und Alters) wurden elektronenmikroskopisch untersucht. In den Kontrolltieren überwiegen die $\beta$-Zellen die reich an Granula sind. Die meisten davon sind Bläschen verschiedener Größe mit einem blassen, körnigen oder homogenen Inhalt. Nur einige weisen einen dichten zentralen Kern auf oder einen unregelmäßigen dichten zentralgelegenen Stab. Die $\alpha$-Zellen haben einheitlich runde und dichte, durch eine Membrane begrenzte Granula und sind spärlich verteilt, außer an der Peripherie der Inseln. Im frühen Diabetes mellitus sind die $\beta$-Zellen in großer Zahl vorhanden aber erscheinen entweder degranuliert oder in verschiedenen Phasen der Glykogenablagerung. In späteren Stadien der Krankheit, als Folge des allmählichen Verschwindens der $\beta$-Zellen, bestehen die Inseln fast nur noch aus $\alpha$-Zellen.

Key-words: Spontaneous diabetes, Chinese hamster, Cricetulus gxiseus, Ultrastructure, Pancreas, Beta cells, Islets, Alpha cells, Nerve endings in pancreas, Glycogen, Basement membrane, Capillaries.
The development of spontaneous, genetically determined, diabetes mellitus in some inbred lines of Chinese hamsters was first reported by MeIer and YERGANIAN [3]. They deseribed predominately beta cells in the pancreatic islets of normal hamsters with scattered peripheral alpha cells. In their diabetic animals beta cells were reduced in number with a relative increase in the number of alpha cells. Degranulation and hydropic degeneration of beta cells was observed. More recently renal changes have been studied in these animals by LAwE [2]. The ultrastructural aspect of the pancreas of this spontaneously diabetic hamster has so far not been evaluated. A colony of these animals for which complete genealogical, clinical and metabolic records are available offers a unique opportunity for evaluation of the

* This work was supported in part by grants GM-03784 and 5 Tl GM-00240 from the Institute of General Medical Sciences, National Institutes of Health, Bethesda, Mary land.

** Permanent address: Institute of General Pathology, University of Rome, Italy. morphologic changes developing in the course of spontaneous diabetes mellitus. This paper is a preliminary report on the ultrastructural pathology of the islets of Langerhans in seven diabetic and eight control Chinese hamsters.

\section{Materials and Methods}

Seven diabetic hamsters and 8 controls (either siblings of the same sex or unrelated animals of the same sex and age) from the Upjohn colony were killed by exsanguination. The pancreas was removed rapidly, cut into cubes of less than $1 \mathrm{~mm}$, and immediately placed in cold, Dalton's chrome-osmium fixative. Fixation was for 2 hours in the cold, and dehydration by $10 \%$ increments in ethanol from 10 to $100 \%$. Tissues were transported back to Washington University in toluene and then infiltrated and embedded in Dow epoxy-resin. Seations approximately $1 \mu$ in thickness were cut for phase microscopy in order to locate islet tissue. Thin sections for electron microscopy were cut on glass knives with a Porter Blum MT-1 microtome. Sections were stained with either lead hydroxide 
or lead citrate prior to examination in an RCA EMU$3 \mathrm{H}$ electron microscope. One micron sections were stained with the periodic acid Schiff reagent and then counterstained with methylene blue for demonstration of glycogen.

\section{Observations}

Control Hamsters. Four types of cells, alpha, beta, a clear cell and an occasional $D$ cell are readily distinguished. The alpha cell seen at the periphery of normal islets has uniformly dense, round granules enclosed by a limiting membrane (Fig. 1). Mitochondria are elongated with irregularly arranged cristae. The endoplasmic reticulum is only rarely arranged as distinct membrane-outlined cisternae with associated ribonucleoprotein granules (RNP). Rather, irregular membranes with attached RNP particles or free ribosomes are prominent in the cytoplasm. Although a distinct Golgi apparatus may be present, it is not as prominent nor as dilated as that in beta cells. Lipofuscin granules, increasingly more prominent with aging, are quite distinctive for alpha and beta cells. In the alpha cell lipofuscin is irregularly rectangular in shape and uniformly dense, or associated with one or two round, homogeneous, less dense zones (Fig. 6 and 9). Plasma membranes of the alpha cells are smooth, here and there surrounding projections of one cell as it invaginates its neighbour. Alpha cells, as is also true of beta cells, are commonly in contact with the basement membranes of the pericapillary space.

Beta cells predominate (Fig. 2) in the islets of the normal hamsters. Beta granules are less dense than those of the alpha cell and more variable in size and density. Dense granules are, for the most part, sparse. Often they have a somewhat dense core surrounded by a paler zone that extends out to the limiting membrane. An occasional granule may have an irregular bar-like structure as a central dense core (Fig. 1 and 2). A majority, however, of the granules in beta cells are membrane outlined with only a pale homogeneous or granular content. In contrast to the alpha cell, linear rough-surfaced endoplasmic reticulum is a fairly constant constituent of the beta cell cytoplasm. Despite its prominence in comparison with the alpha cell, linearly arranged endoplasmic reticulum is a far less prominent feature of their cytoplasm than free ribosomes and vesicular membranes. Mitochondria are variable in shape with distinct transvere cristae. The Golgi apparatus is prominent, perinuclear in position, and usually dilated (Fig. 1, 2 and 3). Beta cells also abut on the pericapillary basement membrane, and indeed often have thin processes that extend there from cells somewhat distant from the vessels. In the beta cell lipofuscin granules are round, either single or confluent, with a pale centre or with numerous vacuoles (Fig. 8).

A third cell type occurs. These rare cells have a clear cytoplasm and cannot be identified further at this time (Fig. 7). They occur both in the control and in the diabetic animals.

Capillaries from control hamsters 12, 21 and 14 months of age respectively are shown in Figures $1-4$. Their endothelium is of the fenestrated type common in endocrine organs. The basement membranes are readily separated into a thin one belonging to the endothelial cell, and into another separating islet cells from the perivascular space per se.

In the hamster, both control and diabetic, nerve endings were frequently in contact with beta cells (Fig. 1 and 2).

It should be mentioned that, as is true in most tissues, there is evidence of degenerative changes in islets of control animals. This is most often seen as cells so filled with lysosomes, lipofuscin and granular debris (Fig. 4) as frequently to be unrecognizable.

Diabetic Hamsters. Early in the course of diabetes in the hamster, beta cells continue to be abundant as is seen in Figure 7 from an animal with glycosuria of 4 months duration. At this stage, however, many of the beta cells are either entirely degranulated (Fig. 6 and 7) or have only a rare granule. The profuse membrane outlined, pale profiles of granules in control hamster beta cells are no longer evident. However, these cells may be readily identified as beta cells by their abundant, dilated Golgi apparatus (Fig. 7), and by a more electron-dense cytoplasm (Fig. 7) than that of the alpha cells, as well as by the morphologic differences in lipofuscin granules in the two cell types. At this stage occasional beta cells, still with recognizable beta granules, are packed with membrane-outlined electron-dense structures (Fig. 7). These apparentIy degenerating or lipid-laden cells contain hypertrophied giant mitochondria.

Glycogen storage is a prominent feature of the beta cell in the diabetic. The degree of storage is variable. In the same field (Fig. 5) some may have only a few granules interspersed along or between membranes of the endoplasmic reticulum. Contiguous cells may have large or small lakes of glycogen pushing cytoplasmic organelles to the periphery. Still other cells are nothing more than sacs of glycogen with a few peripheral organelles and a nucleus (Fig. 7 and 8). The fate of these ballooned, glycogen-packed cells is unknown. Early in the course of glycogen storage within a cell there is a distinct proliferation of roughsurfaced endoplasmic reticulum (Fig. 5 and 6). Its significance in the economy of these sick beta cells is unknown. However, as hamsters with diabetes of longer duration are examined it becomes obvious that fewer and fewer beta cells can be found. The islets become virtually a solid mass of alpha cells (Fig. 9) much as described by FerNer [1]. Beta cells have disappeared. The exact mechanism of this reduction in number remains to be elucidated.

In view of the recent observations on basement membrane thickening in skin of the toe, forearm, ear lobe; gingiva and skeletal muscle in human diabe- 
tics, we have thought it advisable to check blood vessels in all organs of diabetic hamsters examined by electron microscopy. Indeed so far no observations are available on vascular basement membranes in islets of Langerhans in any type of diabetes mellitus. Figures 10 and 11 show capillaries in hamsters diabetic for 13 and 17 months respectively. There is no question as to the thickening seen in Figure 10, nor for that matter in Figure 11, for it would not be possible even with a tangential section to get this amount of basement membrane in the control. Age alone can also be excluded as is shown in Figure 3 from a 22 month old control.

\section{References}

[1] Ferner, H.: Der diabetes mellitus. Chap. VI in Das Inselsystem des Pankreas, pp. 132-174. Stuttgart: Georg Thieme 1952.

[2] LAwE, J.E.: Renal changes in hamster with hereditary diabetes mellitus. Arch. Path. 73, 166-174 (1962).

[3] Meiter, H., and G.A. Yergantan: Spontaneous hereditary diabetes mellitus in Chinese hamster (Cricetulus griseus). 1. Pathological findings. Proc. Soc. exp. Biol, 100, 810-815 (1959).

Dr. Saraf LusE

Department of Anatomy

Washington. University

660 South Euchid Avenue

St. Louis, Missouri, U.S.A. 


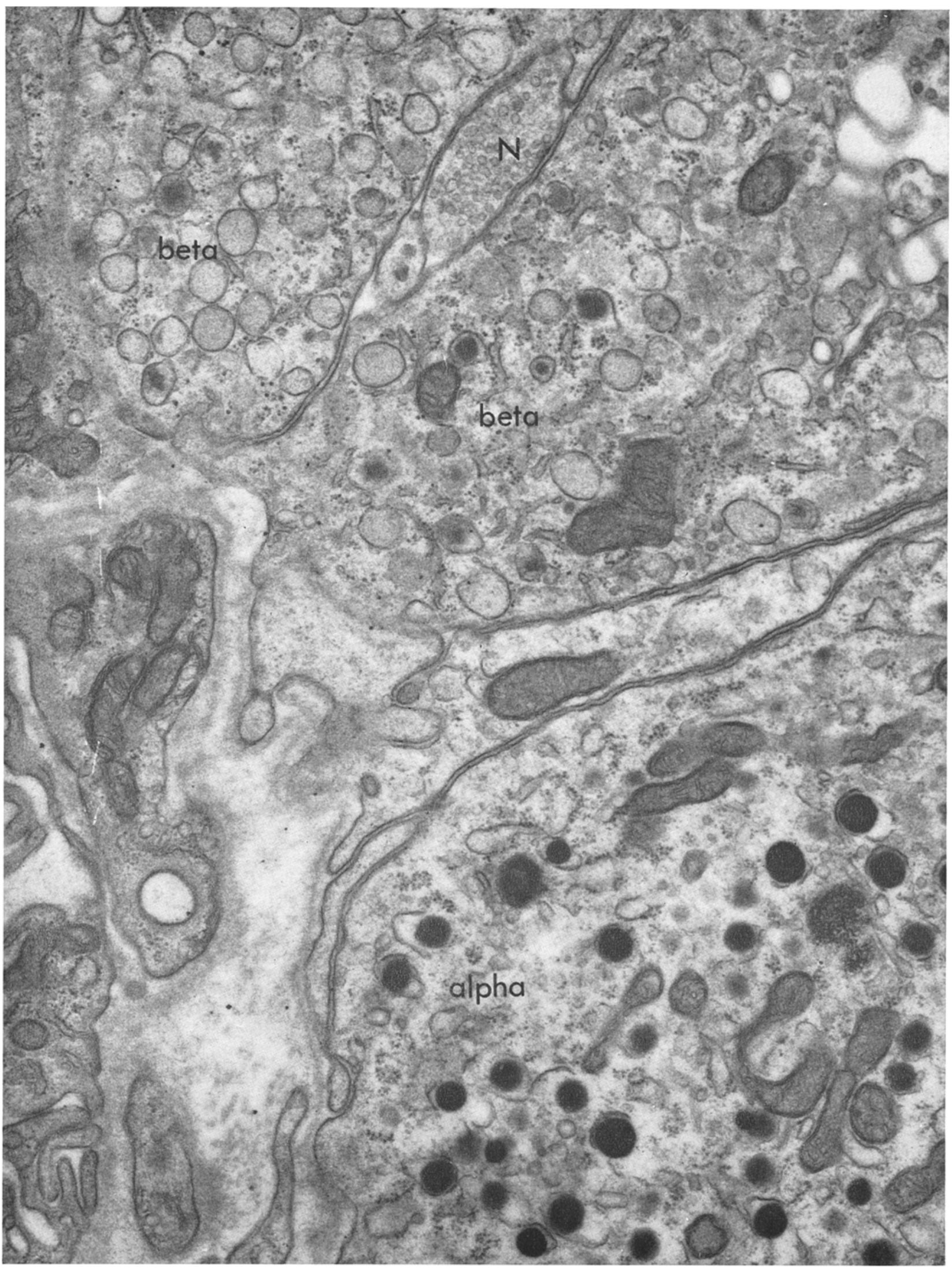

Fig. 1. Islet of Langerhans from a 12 month old control hamster. Part of a blood vessel is seen at the lower left. Parts of 2 beta, cells are present at the top of the figure and part of an alpha cell at the bottom. A small, vesicle-filled nerve process is present between the 2 beta cells ( $N$ ). $29000 \times$ 


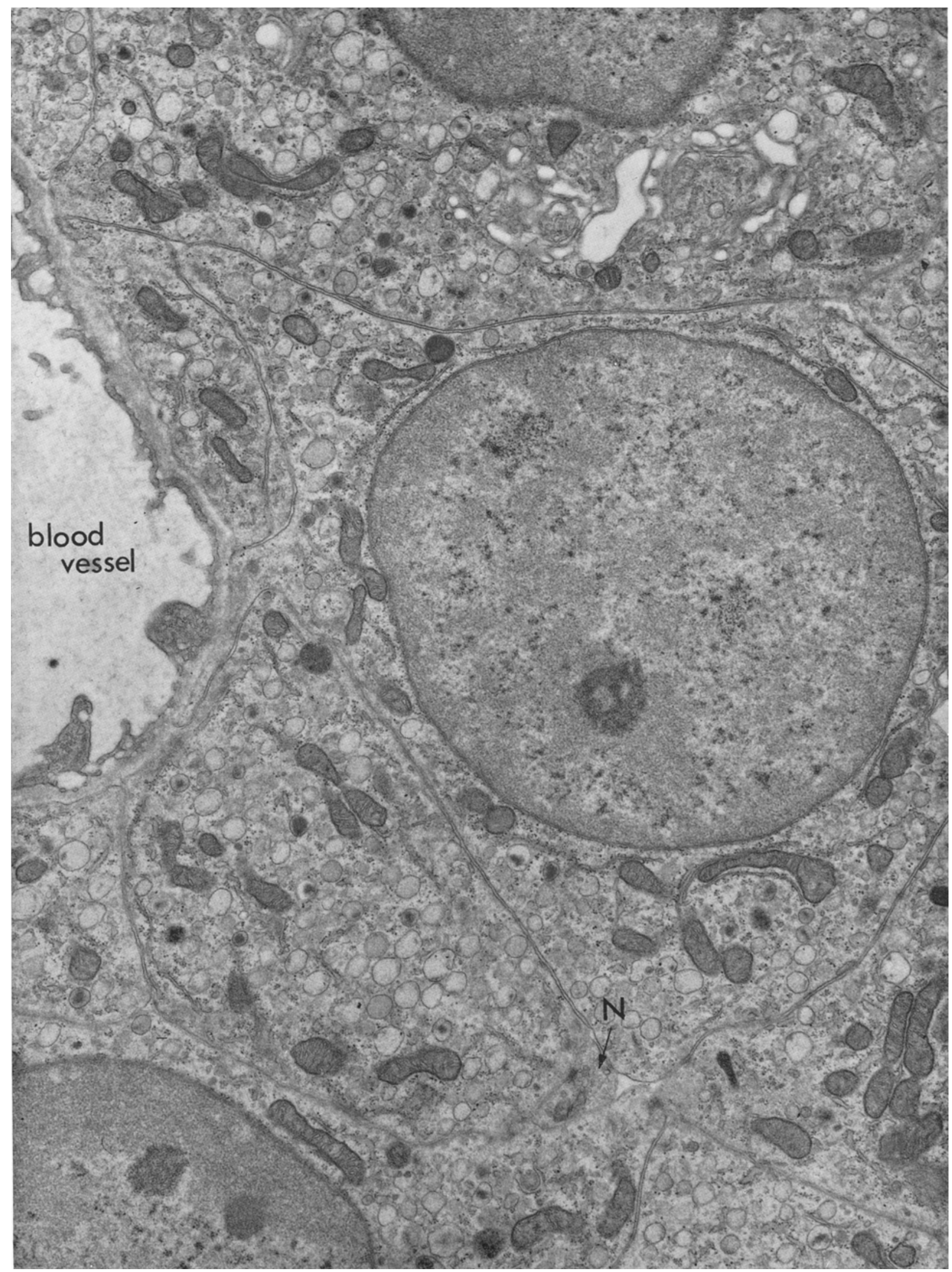

Fig. 2. Tslet from 12 month old hamster to demonstrate the abundant beta cells in the control animals. Parts of 8 beta cells are present around a small blood vessel. The beta cells contain a variable number of granules similar to those described in Fig. 1. Golgi membranes are present in the cell at the top of the plate. A small nerve ending making contact with the cell to its left is present a.t N. $14500 \times$ 

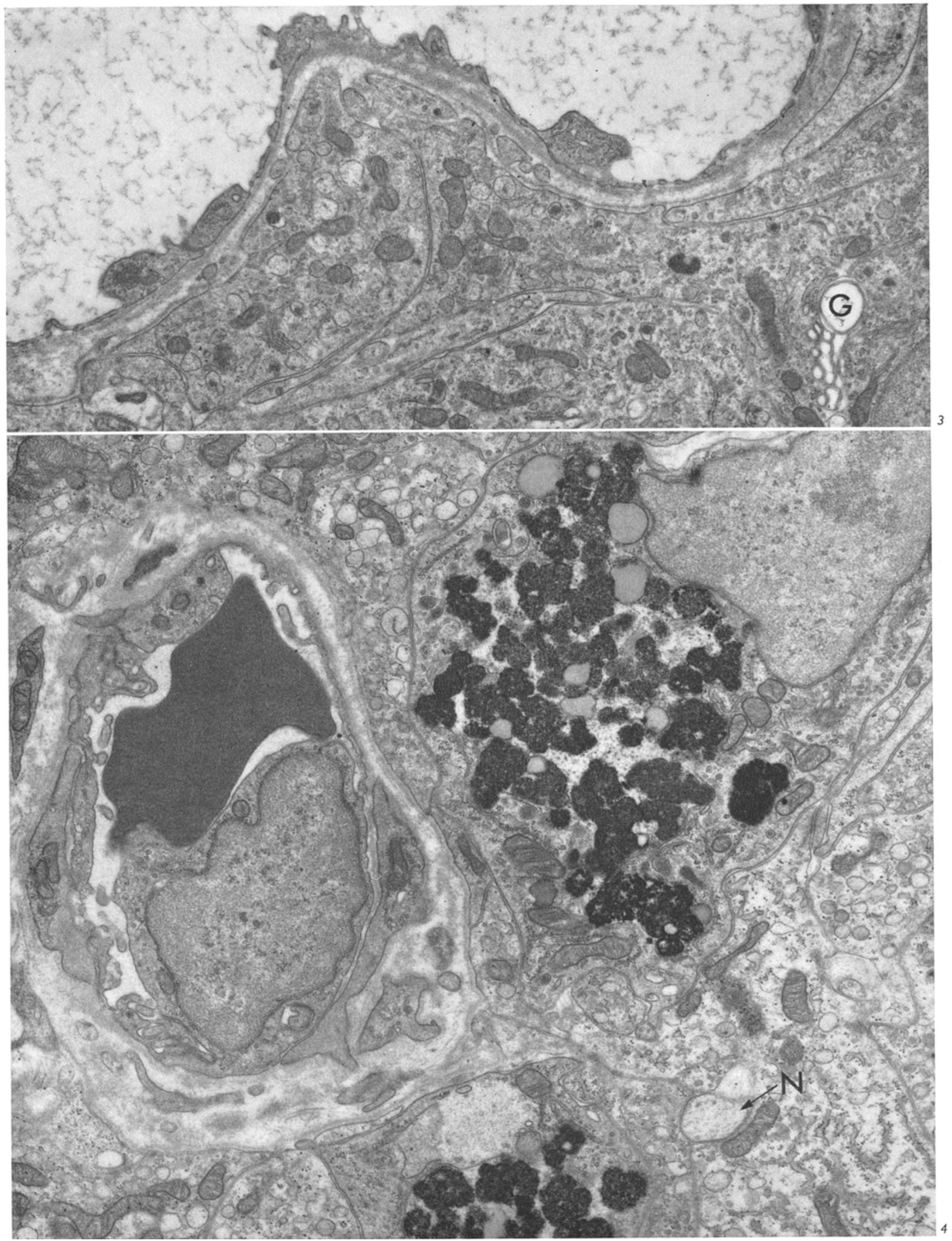

Fig. 3. Parts of 3 beta cells are present around a capillary in an islet from a 21 month old control hamster. The endothelium is fenestrated. The basement membrane at 21 months of age is still delicate. Part of a Golgi apparatus is present at G. $14500 \times$

Fig. 4. Fourteen month old control hamster. A small blood vessel, its lumen filled by a red cell, is present at the left. Cells such as the one at the right are quite rare, but do occur in control animals. The identity of the cell is obscured by the accumulation of lipofuscin in its cytoplasm. A small nerve fibre is present at N. $14500 \times$ 


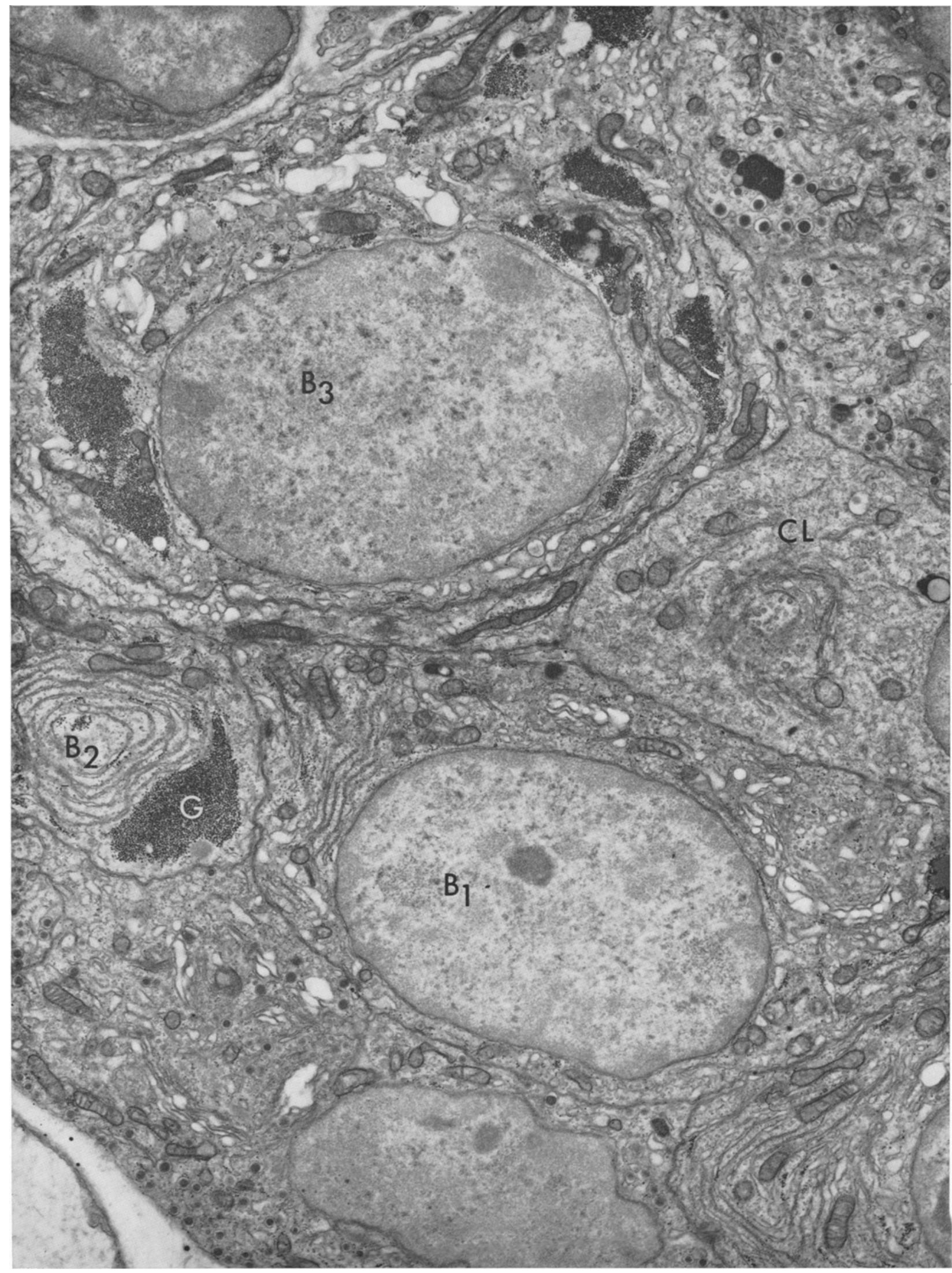

Fig. 5. Twenty-two month old hamster with diabetes mellitus of 20 months duration. Part of an alpha cell is present at the upper right, and of 2 other alpha cells in the lower left. Unidentified clear cells are present at CL. Three beta cells with variable amounts of stored glycogen are evident. In B-1, beta granules are exceedingly scant and there is a delicate dispersion of glycogen amongst the well defined linear endoplasmic reticulum. In B-2 the same fine dispersion of glyeogen is present as well as a large aceumulation (G). The large central beta cell (B-3) has abundant zones of glyeogen aecumulation. $9000 \times$ 


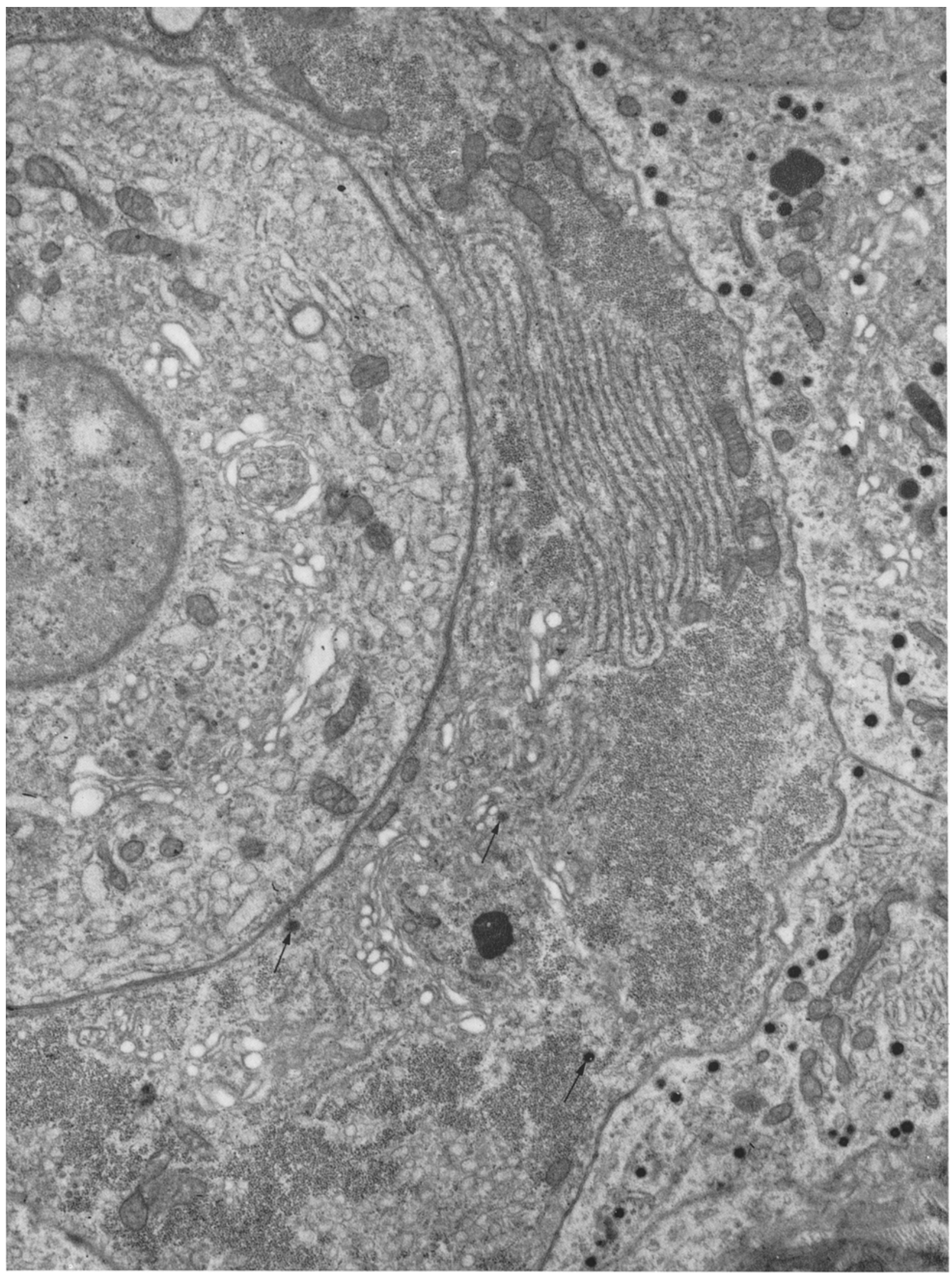

Fig. 6. Ten month old hamster with diabetes of 4 months duration. Two alpha cells are present at the right. The center of the figure is oceupied by the cytoplasm of a beta cell containing large accumulations of glycogen but only rare granules (arrows). This cell demonstrates the marked increase in granular and linearly arranged endoplasmic reticuium in beta cells in diabetes. At the left is part of another almost agranular beta cell. $16000 \times$ 


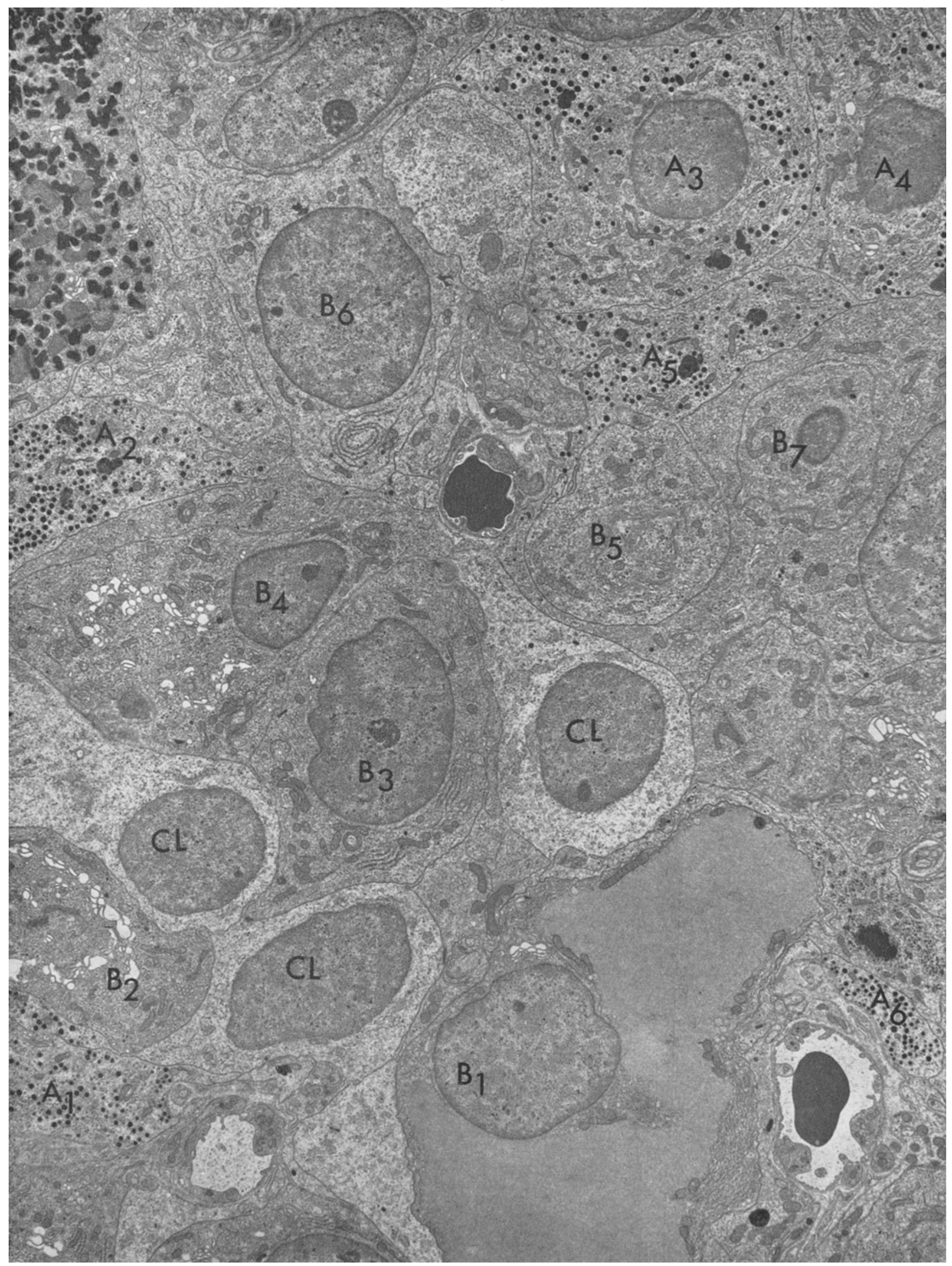

Fig. 7. Another islet from the same diabetic hamster as shown in Figure 6. This! ow power micrograph demonstrates a variety of changes associated with diabetes mellitus. At the lower right $(\mathbf{B}-1)$ is an agranular beta cell whose cytoplasm is a lake of glycogen; (B-2 to $B-7$ are some of the poorly granulated beta cells included in this field). A-1 to A-6 are alpha cells. In the upper left-hand corner there is part of the cytoplasm of an abnormal beta cell in which membrane-bound accumulations of electron-dense material fill the cytoplasm. Golgi membranes and mitochondria are normal. $5000 \times$ 


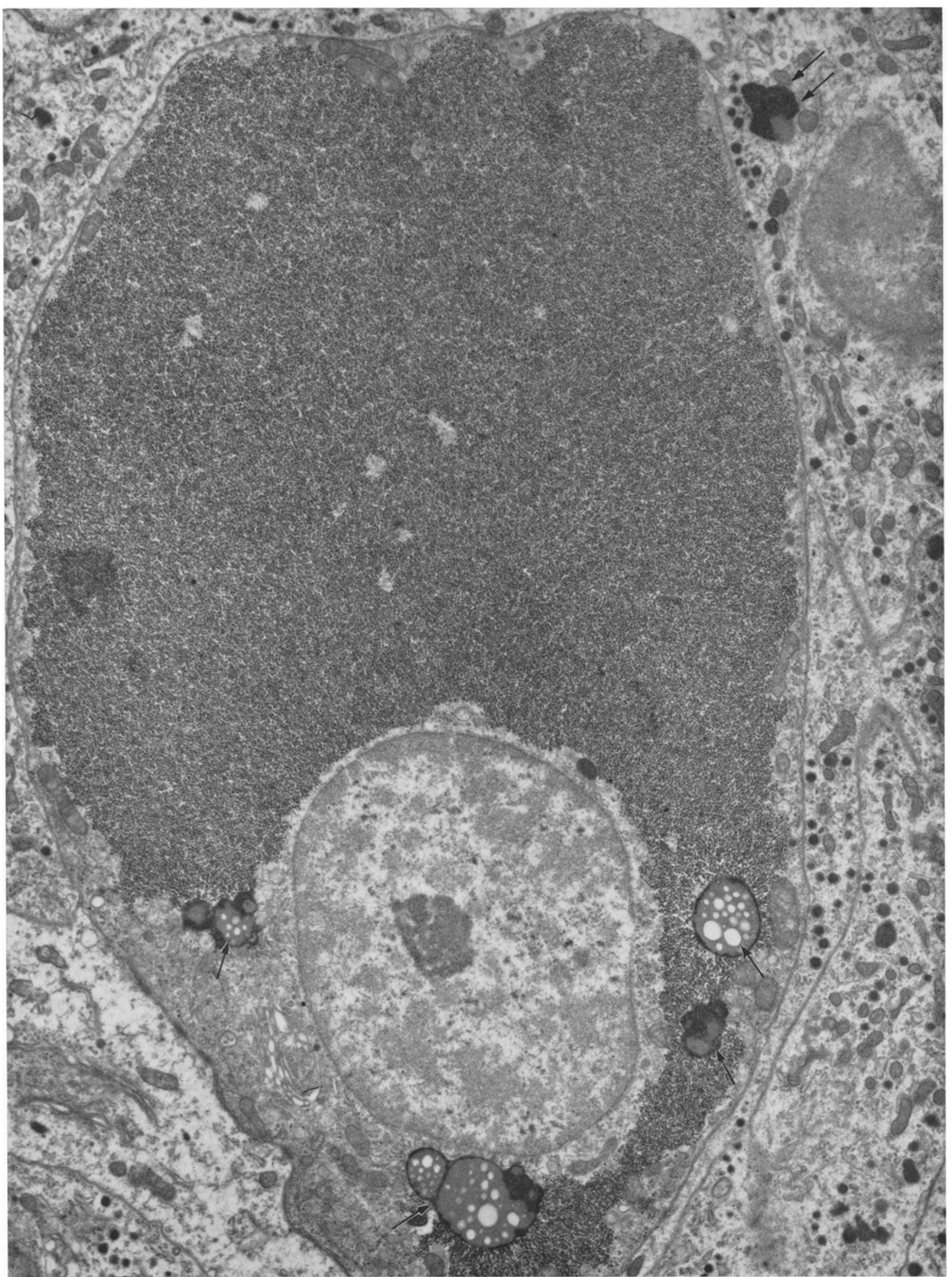

Fig. 8. Hamster, diabetic for 19 months. This beta cell is for all practical purposes a nucleus in a lake of glycogen. Accumulations of lipofuscin (arrows) are characteristic for the beta cell and can be contrasted with the appearance of lipofuscin accumulating in alpha cells as seen at the upper right (double arrow). $10000 \times$ 


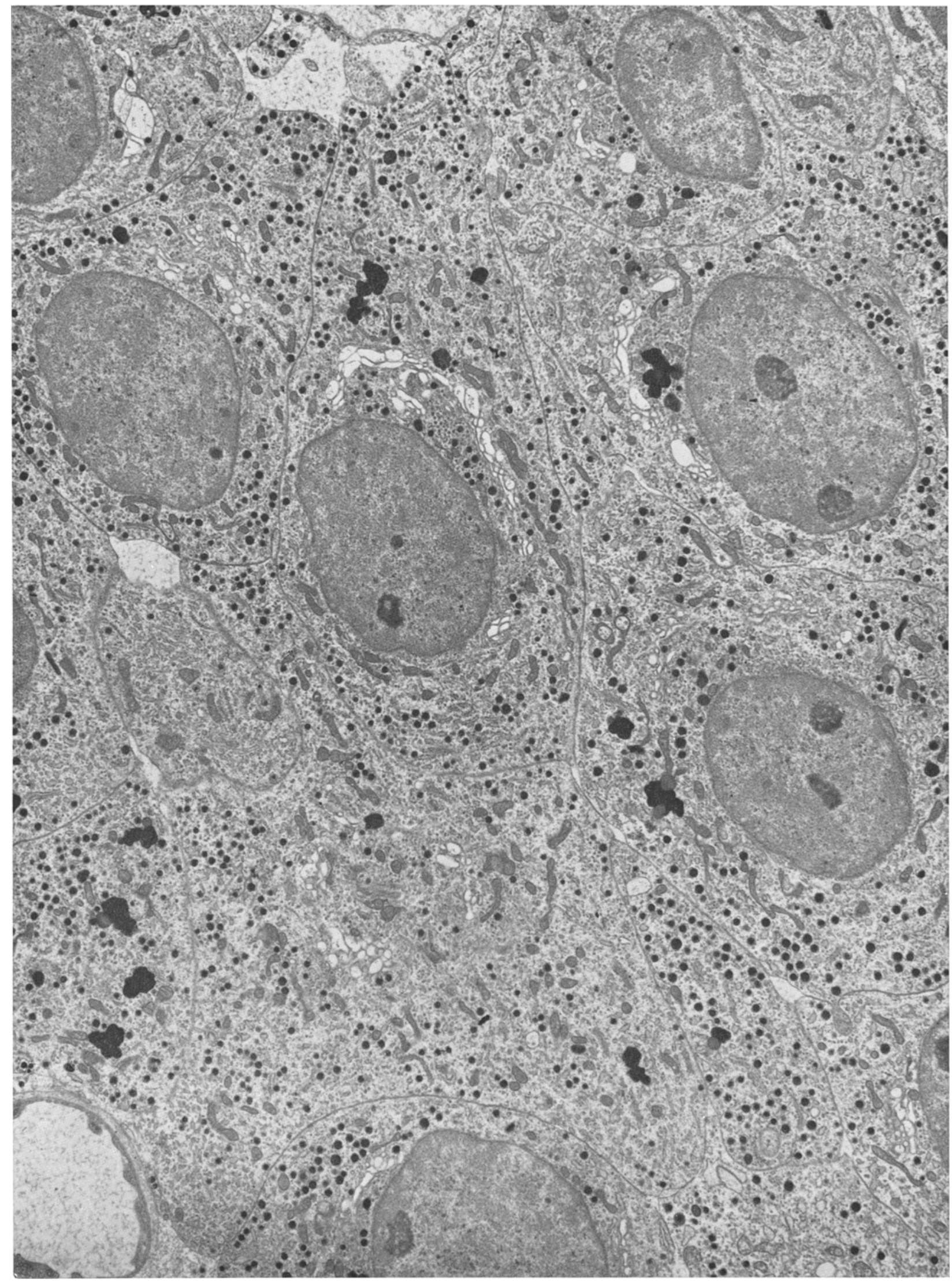

Fig. 9. Hamster, diabetic for 17 months. This low power micrograph graphically points out the predominance of alpha cells in the islets of hamsters that have diabetes of long duration. $8500 \times$ 

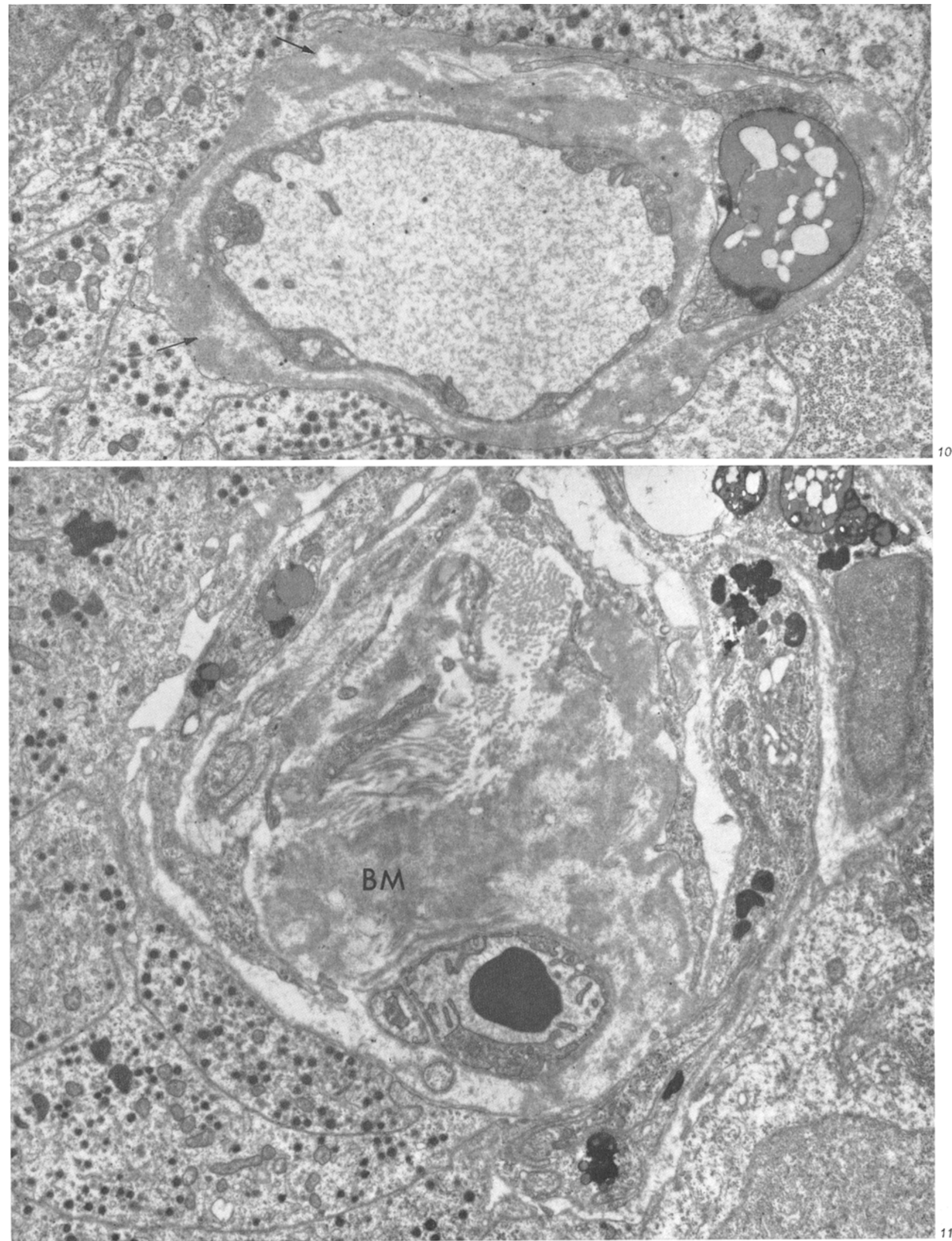

Fig. 10. Capillary in an islet of Langerhans of a hamster diabetic for 13 months. The thick basement membrane (arrows) should be compared with figure $2.15000 \times$

Fig. 11. Capillary from a hamster diabetic for 17 months. The thick basement membrane (BM) is in distinct contrast to that in figures 3 and $4.10000 \times$ 